\title{
Experimental Study of the Effects of Marrow Mesenchymal Stem Cells Transfected with Hypoxia-Inducible Factor-1 $\alpha$ Gene
}

\author{
Jinfu Yang, ${ }^{1}$ Tao Tang, ${ }^{1}$ Feng Li, ${ }^{1}$ Wenwu Zhou, ${ }^{2}$ Jian Liu,, ${ }^{2}$ Zhiping Tan, ${ }^{1}$ Wei Zheng, ${ }^{3}$ \\ Yifeng Yang, ${ }^{1}$ Xinmin $\mathrm{Zhou}^{1}$ and Jianguo $\mathrm{Hu}^{1}$ \\ ${ }^{1}$ Department of Cardiothoracic Surgery, Second Xiangya Hospital, Central South University, Hunan, Changsha 410011, China \\ ${ }^{2}$ Department of Cardiothoracic Surgery, Hunan Children's Hospital, Hunan, Changsha 410007, China \\ ${ }^{3}$ Department of General Surgery, Human Provincial People's Hospital, Hunan, Changsha 410005, China
}

Correspondence should be addressed to Tao Tang, tangtao2001@163.com

Received 11 February 2009; Revised 9 April 2009; Accepted 15 April 2009

Recommended by Omar Benzakour

Objective. To construct the eukaryotic expression vector hypoxia-inducible factor $1 \alpha-\mathrm{pcDNA}_{3.1}$ and to investigate its transfective efficiency into mesenchymal stem cells (MSCs) in vitro and the expression of HIF- $1 \alpha$ gene in MSCs. Methods. mRNA of Wistar Rats' myocardial cells was extracted, and cDNA was synthesized with Reverse Transcription Kit, HIF-1 $\alpha$ was amplified by

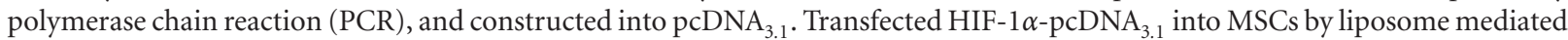
method. The expression of HIF- $1 \alpha$ in the cells was detected by Western Blot Analysis and ELISA. Results. Eukaryotic expression vector HIF- $1 \alpha$ - cDNA $_{3.1}$ was constructed successfully. Analyzed by flow cytometer, The MSCs' surfaces mark were CD44+, $\mathrm{SH} 3(\mathrm{CD} 73)+, \mathrm{CD} 34-, \mathrm{CD} 45-$ and the CD44+ cells and SH3(CD73)+ cells were $94.7 \%$ and 97.3\%, respectively, showing the high purity of the cultured MSCs. After inducing, the cultured MSCs can differentiate into osteoblasts and adipocytes successfully. In HIF- $1 \alpha$ gene transfected MSCs, the expression of HIF- $1 \alpha$ mRNA and HIF- $1 \alpha$ protein were both increased obviously. Conclusion. HIF- $1 \alpha$ was cloned successfully. HIF- $1 \alpha$-pcDNA ${ }_{3.1}$ can be transfected into MSCs by liposome-mediated method effectively and which resulting stable expression of HIF- $1 \alpha$ in transfected MSCs.

Copyright (C) 2009 Jinfu Yang et al. This is an open access article distributed under the Creative Commons Attribution License, which permits unrestricted use, distribution, and reproduction in any medium, provided the original work is properly cited.

\section{Background}

The pathological mechanism of ischemic heart disease (IHD) is thought that the irreversible loss of the functional cardiomyocytes, which are eventually replaced by fibrous noncontractile cells, followed by ventricular remodeling and than congestive heart failure. Due to the high occurrence and mortality, the IHD has become one of the most serious diseases which jeopardize human health [1]. One of the present research hot point for IHD is therapeutic angiogenesis, which can be achieved by three ways, that are the growth factor protein therapy, cell transplant and gene therapy. There were some clinical trials using naked plasmid vascular endothelial growth factor-A165 to treat patients with stable angina pectoris [2] or with severe chronic ischemic heart disease [3]. Although these two studies suggested that the gene treatment was safe, the clinical significance of gene therapy has not been demonstrated convincingly which emphasizes the need for new treatment modalities, that is, the exogenous therapeutic gene transfected MSC.

Hypoxia-inducible factor- $1 \alpha(\mathrm{HIF}-1 \alpha)$ is a transfectedactive nucleoprotein induced by cells under hypoxia conditions, which can enhance the production of corresponding proteins and launches the process of angiogenesis by binding to the hypoxia response elements (HRE) of the vascular endothelial growth factor (VEGF), transforming growth factor- $\beta$ and their receptors, and in turn improves the cardiomyocytes' adaptability to ischemic condition. Gene therapy using HIF- $1 \alpha$ as the target gene has two major advantages; one is higher effect than other downstream genes such as VEGF, ANG-2 and the other is the feasibility of control because of lower risk of resulting angioma.

Marrow mesenchymal stem cells (MSCs), early cells of the mesoderm, are present in adult marrow tissue. These cells can "self-renew" and have the plasticity to differentiate into multiple tissues. Some advantages of MSCs are that they can 
be isolated easily from a variety of sources, have genetic stability, and do not carry immunological or ethical concerns. Hence, they were considered very suitable candidate donor cells for stem cell therapy. And therefore, transplantation of MSCs transfected with HIF1 $\alpha$ into infarcted heart area may have a synergic effect in myocytes regeneration and angiogenesis which contribute to better outcome than either gene therapy or cell therapy alone.

\section{Materials and Methods}

The Wistar rats (Laboratory Animal Center, the 2nd Xiangya Hospital, Central South University) received humane care in compliance with the "Guide for the Care and Use of Laboratory Animals" prepared by the Institute of Laboratory Animal Resources, National Research Council, and published by the "Guide to the Care and Use of Experimental Animals" by the Chinese Council on Animal Care.

2.1. RNA Extract and Analysis. RNA was extracted according to protocols listed in the commercially available kit. The quality of resulted RNA samples was assayed by the absorption value in $260 \mathrm{bp}$ and $280 \mathrm{bp}$ (value of OD260/280 between 1.8 to 2.0 indicating high purity) and the yield of RNA was calculated according to 1 OD260 equals to $40 \mu \mathrm{g}$ RNA. Finally, the integrity of the extracted RNA and contamination of DNA were determined by formaldehyde denaturation agarose electrophoresis.

2.2. Synthesis of cDNA. cDNA was synthesized by a Reverse Transcription System Kit (Promega) following the protocols listed in instructions.

2.3. HIF-1 $\alpha$ PCR Amplification (GenBank's Reception Number: EF100708). The primers for PCR were designed by using NCBI's site based on Wistar rats' HIF- $1 \alpha$ mRNA sequences from GenBank. The Wistar rats' specific primers for HIF$1 \alpha$ mRNA were designed by using Primer 3 software. The forward primer was $5^{\prime}$-ATG GAG GGC GCC GGC GG$3^{\prime}$, with a Hind III restriction enzyme cutting site being inducted. The reverse primer was $5^{\prime}$-GTT AAC TTG ATC CAA AGC TCT-3', with a BamH I restriction enzyme cutting site being inducted. The length of amplified segment was 2480 bp.

PCR products were detected by electrophoresis in $1 \%$ agarose gel. Cut off the gel carrying target segment under viltalight lamp. Retrieved and purified the target gene segment by using gel extraction Kit, then cloned TA as routinely.

2.4. Cloning of HIF-1 $\alpha$ to T Vector. The RT-PCR products of HIF- $1 \alpha$ 's coding region were cloned to pGEM-T vector. HIF$1 \alpha$ was subcloned to $\mathrm{pcDNA}_{3.1}$ vector.

2.5. Isolation, Culture, and Identification of MCSs. Mesenchymal stem cells (MSCs) from 6 weeks old Wistar rats were obtained by density gradient centrifugation and purified on the basis of their ability to adhere to plastic. In short, the cells were isolated from the bone marrow of limb bones and separated by gradient centrifugation with $1.073 \mathrm{~g} / \mathrm{mL}$ Percoll solution (Promega, USA). The cells were cultured in low carbohydrate Dulbecco's modified Eagle's medium (Gibco $\mathrm{BRL}, \mathrm{USA})$ at $37^{\circ} \mathrm{C}$ in a humidified atmosphere containing $5 \%$ carbon dioxide (Forma, USA).

Cytoactive detection of MCSs: $20 \mu \mathrm{L}$ MSCs heavy suspensions were stained with typan blue, which turned the dead cells blue while the living cells remained unstained, then counted the total cellular scores in the four big squares of the cell counting chamber. Counted 200 MSCs, and calculated the ratio of living cells by using the formula: living cells percentage $=$ viable count $/$ total cell count $\times 100 \%$.

The growth curve in day 1 to day 11 of MSCs was drawn. After MSCs were cultured in vitro for 4 weeks, Flow cytoMeter (FCM) (FACSort, B-D Co., USA) was used to analyze the superficial markers such as CD34, CD44, CD45 and SH3 of MSCs. Osteoblast differentiation from MSCs was induced by dexamethasone, $\beta$-glycerol phosphate and ascorbic acid, and shown by alizarin S on day 14 . Adipocyte differentiation from MSCs was induced by insulin and shown by Sudan IV on day 21.

\subsection{HIF-1 $\alpha$ Gene Transfect into MSCs}

2.6.1. Extraction and Identification of Plasmid. The bacterial fluid was shifted into $500 \mathrm{~mL}$ centrifuge tubes and centrifugated at $4{ }^{\circ} \mathrm{C}$ with the speed of $12,000 \mathrm{rpm}$ for 10 minutes, and the supernatant was removed. Plasmid was extracted by using QIAGEN Plasmid Maxi Kit following the protocols listed in instructions. The extracted products were cut by Enzyme Hind III and Enzyme BamH I, and then detected by electrophoresis in $1 \%$ agarose gel. The extracted products were cut by enzymes at $37^{\circ} \mathrm{C}$ according to the following bienzyme cutting system: HIF- $1 \alpha$-pcDNA ${ }_{3.1} /$ eGFP (National Key Genetic Laboratory, China) plasmid $1 \mu \mathrm{g}$, Hind III 2U, BamH I 2U, Kbuffer $2 \mu \mathrm{L}$, water added up to $20 \mu \mathrm{L}$, enzyme cutting with water bath at $37^{\circ} \mathrm{C}$ for 4 hours, then detected by electrophoresis in $1 \%$ agarose gel.

2.6.2. HIF-1 $\alpha-p c D N A_{3.1} / e G F P$ Transfect into MSCs Mediated by Lipofectamine2000. After several methods about tranfection were tested, the following procedure of tranfection was finally used. Briefly: 24 hours before the transfection, the 4th generation MSCs, whose growth confluence rate reached around $80 \sim 90 \%$, were digested by $0.05 \%$ Trypsin $/ 0.02 \%$ EDTA and than vaccinated to 12-pore plates with apinoid sterilized round cover glasses (about $1 \times 10^{5} \mathrm{MSCs} /$ pore, each pore containing $1 \mathrm{~mL}$ L-DMEM culture solution with $15 \%$ fetal bovine serum) and cultured in an incubator with carbon dioxide at $37^{\circ} \mathrm{C}$ in a saturated humidity atmosphere containing 5\% carbon dioxide. The MSCs were transfected with HIF- $1 \alpha$-pcDNA . $_{3.1} /$ eGFP plasmid by using Lipofectamine2000 Kit following the protocols listed in instructions strictly. The fluid was changed totally after culturing for 24 hours; about $10 \%$ of the dead cells were removed with the abandoned fluid. The rest was cultured for passage and amplification until reaching $80 \sim 90 \%$ confluence.

2.6.3. Detection of the Expression of HIF-1 $\alpha$ Gene in Target Cells. The marker gene, eGFP, can be expressed at the same 
chronergy of the target gene. The expression of marker gene observed by fluorescence can reflect the expression of target gene indirectly. The transfected cells were taken out of the incubator at different time. The expression of fluorescence was observed by using invert microscope with the excitation wave length of $490 \mathrm{~nm}$.

Hoechst 33342 is a DNA binding fluorescence dyes used to dye living cells owing to its ability of penetrating intact cell membranes and can give out blue fluorescence with the action of excitation light at $350 \mathrm{~nm}$. We used Hoechst 33342 marked nucleus as total cell number, and eGFP marked nucleus as transfected cell number to assay the transient transfection efficiency.

To detect the expression of HIF- $1 \alpha$ at transcriptional level, RT-PCR was used. The forward primer was $5^{\prime}$-ATGGAGGGCGCCGGCGG-3' , the reverse primer was $5^{\prime}$-GTTAACTTGATCCAAAGCTCT-3'. The length of the product was $2480 \mathrm{bp}$. Inner reference was GAPDH, its forward primer was 5'-GGGGTGAGGCCGGTGCTGAGTA-3', the reverse primer was $5^{\prime}$-CATTGGGGGTAGGAACACGGAAGG-3' . The length of the product was $459 \mathrm{bp}$. PCR products were detected by electrophoresis in $2 \%$ agarose gel. Bio-Rad image analysis software was used as semiquantitative analysis of the absorbance capacity. The relative amount of HIF$1 \alpha$ mRNA $=$ absorbance value of HIF- $1 \alpha$ 's amplification product/absorbance value of GADPH's.

To detect the expression of HIF- $1 \alpha$ protein in supernatant, ELISA was used. The medium of HIF- $1 \alpha$ gene transfected and nontransfected MSCs were loaded on 6 pores separately and ischemic and anoxic preconditioning for 2 hours while reaching 80 90\% confluence, then abandoned the culture solution. Washed twice with the precooled PBS and fully schizolyed by Schizolysis balanced solution (Tris $50 \mathrm{mM}$, EDTA $3 \mathrm{Mm}, \mathrm{MgCl}_{2} 1 \mathrm{mM}, 1 \%$ Triton X-100), cells were collected and centrifugated at $16000 \mathrm{rpm} 4^{\circ} \mathrm{C}$ for 10 minutes, then the supernatant was collected and subpackaged. Following the protocols listed in the instructions manual strictly, the rat ELISA kit was used. The standard immunoreagent was diluted to $1 \mathrm{~mL}$ with sample dilution and its density were $10000 \mathrm{pg} / \mathrm{mL}, 5000 \mathrm{pg} / \mathrm{mL}, 2500 \mathrm{pg} / \mathrm{mL}$, $1250 \mathrm{pg} / \mathrm{mL}, 625 \mathrm{pg} / \mathrm{mL}, 312 \mathrm{pg} / \mathrm{mL}$, AND $156 \mathrm{pg} / \mathrm{mL}$, as series multiproportion dilution. The stock solution was considered as the highest normal concentration directly, the sample diluent was considered as normal concentration $0 \mathrm{pg} / \mathrm{mL}$, it was dispensed in 15 minutes before using it. Diluted the supernatant liquid according to the ratio sample diluent : supernatant $=1: 20$, then detected it.

To detect the expression of HIF- $1 \alpha$ protein in MSCs, Western Blot was used. Concentration of the protein was detected by using Bradford. In brief, $2 \times$ sample buffer was added to equivalent sample according to concentration of the protein, denaturated at $100^{\circ} \mathrm{C}$ for 5 minutes, then performed SDS-PAGE electrophoresis $(25 \mu \mathrm{g} /$ pore $)$ at constant voltage $120 \mathrm{v}$. After that, protein was transferred to NC membranes (Nitrocellulose membranes) at $120 \mathrm{v}$ for about 2 hours. Subsequently, the membrane was blocked by a blocking buffer (5\% dried skim milk, $25 \mathrm{~mm}$ Tris-buffer saline TBS) for 2 hours. Followed by incubation with rabbit antirat HIF- $1 \alpha$ antibody (diluted 1 : 1000, GAPDH $1: 10000$ )

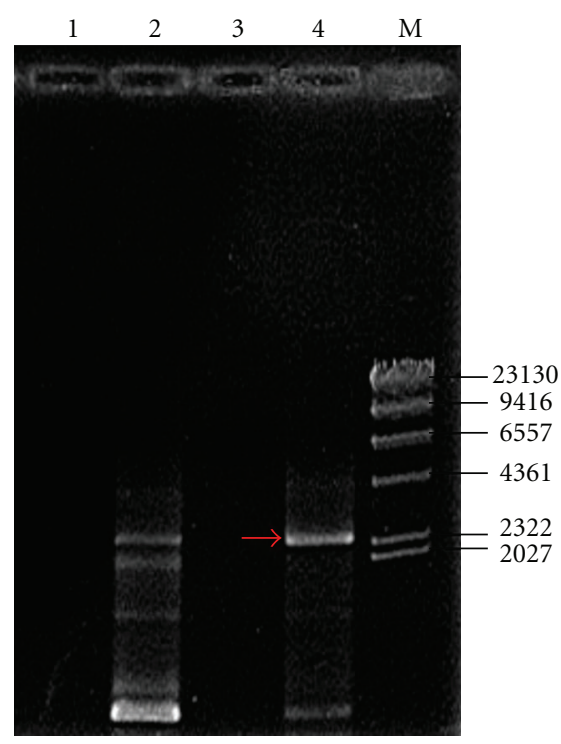

FIGURE 1: HIF- $1 \alpha$ expression by RT-PCR is shown by the red arrow. Lanes 1 and 3 are negative control and lane 2 denaturated at $58^{\circ} \mathrm{C}$, lane 4 at $62^{\circ} \mathrm{C}$. Lane $\mathrm{M}$ is $\lambda \mathrm{DNA} / \mathrm{Hind}$ III.

at room temperature for 1 hour. Next the membrane was washed three times with TBST for $10 \sim 15$ minutes each time, incubated with horseradish peroxidase-conjugated secondary antibody (diluted $1: 1000$ ) and antiGAPDH mono-antibody at room temperature for 1 hour, and washed again. Finally ECL reagent was added. 5 minutes later the film was exposed, developed and fixed. The analysis of absorbance was done by using Genesnap/Genetools software. Relative expression of protein in each group was expressed by contral: GAPDH.

\section{Results}

3.1. Amplification of RT-PCR. The HIF-1 $\alpha$ production amplified by primer 1 and primer 2 were, as predicated, located near $2480 \mathrm{bp}$ (Figure 1 ). The renaturation temperature of lanes 2 and 4 were $58^{\circ} \mathrm{C}$ and $62^{\circ} \mathrm{C}$, respectively, and the positive expression can be observed at lane 4 more pronounced.

3.2. Identification of HIF-1 $\alpha$ Plasmid. White clone $1 \sim 3$ was double digested with EcoR I and Sal I (Figure 2(a)). T vector band (about $3000 \mathrm{bp}$ ) and HIF- $1 \alpha$ band (about $2480 \mathrm{bp}$ ) were showed in clones 1 and 2, which were positive clones and can be verified by sequencing analysis. HIF- $1 \alpha$-pcDNA p $_{3.1}$ and $\mathrm{pcDNA}_{3.1}$ empty vector were digested with Hind III and BamH I, the objective bands were cut under ultraviolet lamp and ligated overnight in vitro. Then the ligation product was transformed into JM109 escherichia coli, followed by manual plasmid extraction and identification by double digestion (Figure 2(b)).

3.3. Sequencing Analysis. The base sequence of inserted gene into pcDNA $_{3.1}$ was completely coincidence with the sequence of HIF- $1 \alpha$ by GenBank. 


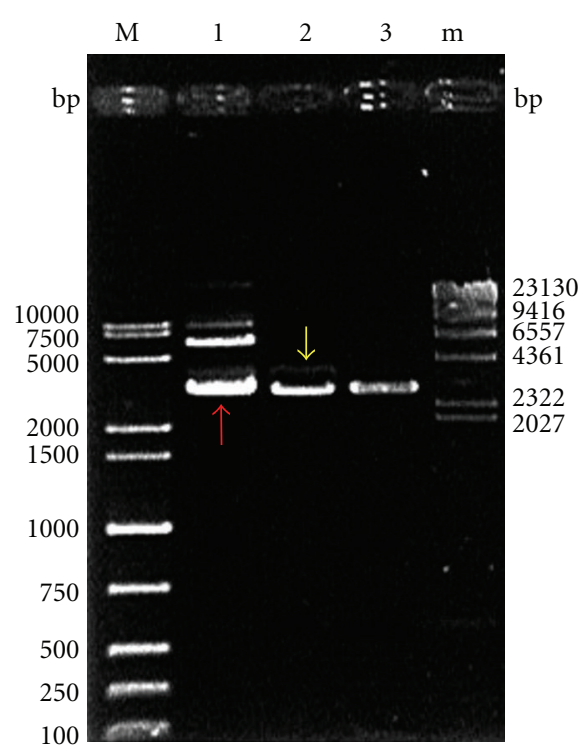

(a)

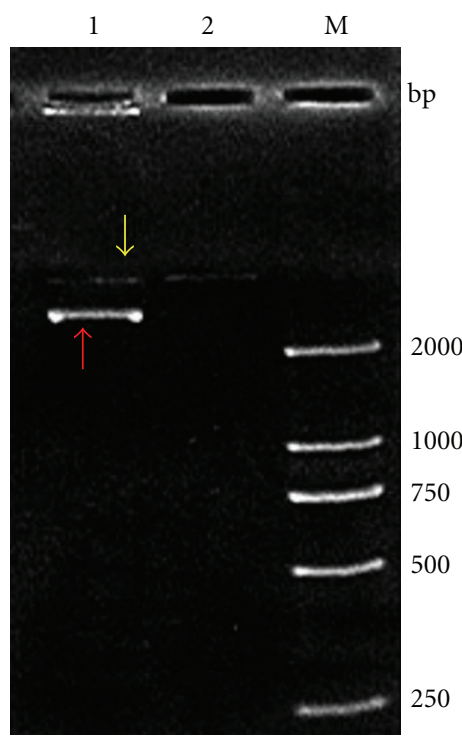

(b)

Figure 2: (a) The results of HIF- $1 \alpha$-T vector double digestion with EcoR I and Sal I. 1-3: Clones 1-3; m: $\lambda$ DNA/Hind III; M:DNA marker; Clones 1 and 2 were positive clone. Red arrow showed the HIF-1 $\alpha$ band, and yellow arrow showed the T vector band. (b) The results of

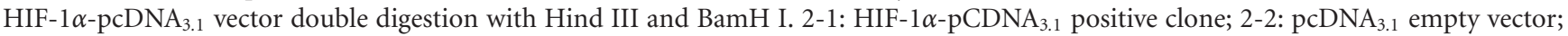
M: DL 2000. Red arrow showed the HIF- $1 \alpha$ band, and black arrow showed the pCDNA $_{3.1}$ vector band.

\subsection{Isolation, Culture, and Identification of MCSs}

3.4.1. The Growth and Morphologic Characters of MSCs. A layer of monocyte between the separating medium and the rinse solution was obtained by adding $1.073 \mathrm{~g} / \mathrm{mL}$ Percoll solution in MSCs. The MSCs were adhered to the culture bottles 24 hours after the plantation with fusiform shapes, and 72 hours later these cells' attachments became much more pronounced and most of them begin to expand to form pseudopodia. 3-5 days after the plantation, those suspension cells that underwent necrosis were removed. The remained MSCs proliferated in colonies and after cultured for 6-7 days, the nucelus enlarged which contains 1-3 nucleolus. The extracellular connects were formed gradually as the proliferating of cell colonies which irradiate from single points or arranged in a vortex. 10-12 days later, the cell confluens reached to $80-90 \%$ and the primary culture ended (Figure 3). After passage, the new daughter MSCs begin to adhere within few hours and completely adhere to bottlers within 24 hours and then entered to the logarithm proliferative phase during which the number of MSCs doubled within 2-3 days and confluened within 5-7 days in spindle, triangle and polygon shapes with pronounced nucleus. The resulted MSCs after 3-5 times passage kept a high proliferative speed and the speed began to slow down after 7 times passage and faded gradually.

3.4.2. Identification of the Surface Markers of MSCs. The growth curve of 3rd and 5th generation MSCs had the shape of S; the OD value was not changed markedly at the first 1-2 days (incubation phase), followed by the logarithmic growth phase during which the cells proliferated quickly occurred at
2-3 days and then by platform phase during which cellular contact inhibition occurred at 6-8 days. The mean passage period was 6-8 days (Figure 4).

Immunophenotypic analysis by FACS of cells after fourcell passages showed that cells expressed high level of CD44 (94.7\%) and $\mathrm{SH} 3$ (97.3\%). Cells did not express CD34 $(3.84 \%)$ or CD45 (2.73\%) (Figure 5).

3.4.3. Differentiation of MSCs. After 14 days, a mass of calcium salinity accumulated (Figure 6), which was red when stained by alizarin $\mathrm{S}$ (Figure 7).

The shape of cells changed after day 14 of induced culturing and few fat drops appeared (Figure 8). After 21 days, more than $80 \%$ of cells differentiated into lipid-laden cells which were stained by Sudan IV (Figure 9).

\subsection{Transfection of HIF-1 $\alpha$ into MSCs}

3.5.1. Observation of Fluorescence and Transient Transfection Efficiency. Weak and little fluorescence was found at 12 hours after transfection under fluorescence microscope; at 24 hours, dark green fluorescence appearred; during 48 72 hours, positive cells increased and fluorescent intensity strengthened; fluorescent intensity reached the peak level at 72 hours and lasted about 1 week, which became bright green fluorescence; then the intensity decreased, but localized and diffuse fluorescence can be found continued to 4 weeks. With the best transfection program, the transfected cells can maintain favorable growth cycle, and the cells in each phase displayed the proliferation or division state can be observed (Figure 10). 


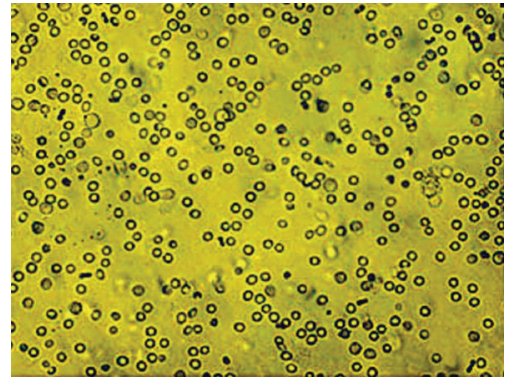

(a)

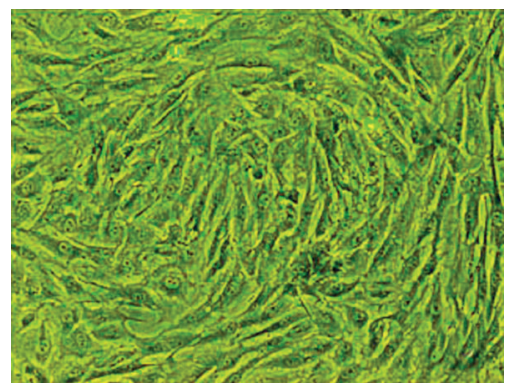

(d)

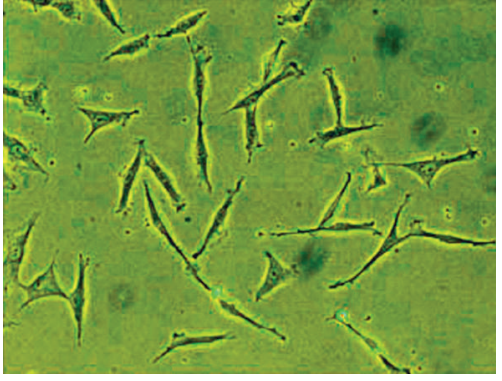

(b)

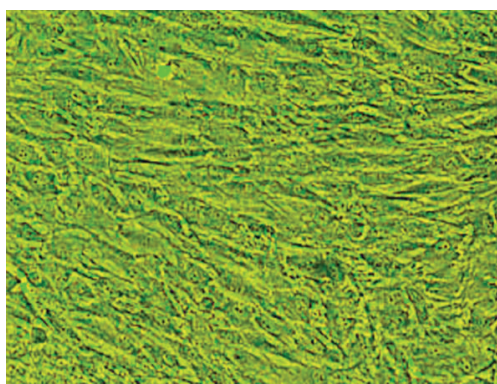

(e)

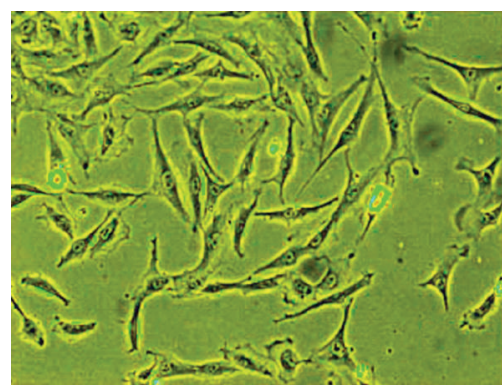

(c)

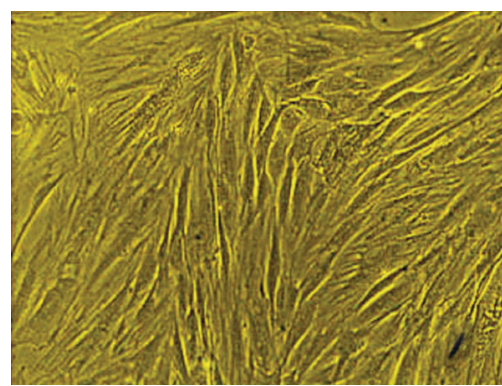

(f)

Figure 3: Morphology of MSCs in primary culture $(100 \times)$. The primary cultured cells floated in medium and had a uniformed globular shape (a). 3-4 days later, the cells adhered to the bottle began division growth (b) and the proliferated cell had a long fusiform shape containing 1-3 nucleolus 5-6 days later (c). The cell colony can be seen 7-9 days later (d) and contact inhibition can be observed 10-12 days later (e). The 3rd generation MSCs was well-distributed as fibroblast.

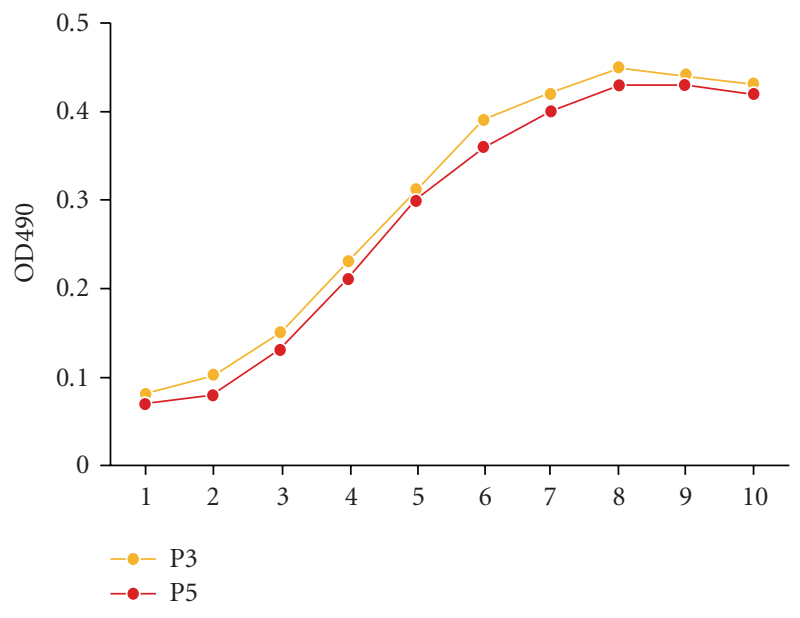

Figure 4: The growth curve of MSCs.

The transfer efficiency is affected greatly by many factors. In this study, fews tranfection procedures were attempted to obtain the optimal transfection rate. When the mix proportion of DNA and liposome was $1: 3(\mu \mathrm{g}: \mu \mathrm{L})$, cell density was $\left(1 \times 10^{5} / \mathrm{mL} /\right.$ pore $)$, incubation time was 5 hours and cell confluence was $78-80 \%$, and the transfer efficiency rate is $16.3 \%$ (Figure 11 ).

3.5.2. RT-PCR. The results from gene transfected or nontransfected MSCs were shown in Figure 12. The length of GAPDH production was $459 \mathrm{bp}$ and the length of HIF- $1 \alpha$ was $2.5 \mathrm{~kb}$. Under hypoxia conditions, both HIF- $1 \alpha$ gene transfected (lane 1) and nontransfected (lane 2) MSCs can express HIF- $1 \alpha$, but the expression in the gene transfected group was higher.

3.5.3. ELISA. ELISA found that both gene transfected and nontransfected MSCs produce HIF- $1 \alpha$ protein, but the concentration was higher in the transfected group (Figure 13).

3.5.4. Western Blot. The protein lanes from gene transfected or nontransfected MSCs were shown in Figure 14. The length of GAPDH production was $37 \mathrm{KD}$ and the length of HIF- $1 \alpha$ was $120 \mathrm{KD}$. Under hypoxia conditions, both HIF- $1 \alpha$ gene transfected (lane 1) and nontransfected (lane 2) MSCs can express HIF- $1 \alpha$, but the expression in the gene transfected group was higher.

\section{Discussion}

Hypoxia inducible factor- $1 \alpha$, a transcriptional neucleoprotein synthetized by cells subjected in hypoxia circumstance, is the first discovered heterodimeric DNA-binding complex which can bind with the hypoxia response element in the reinforce factor of erythrogenin gene. And after binding with the target gene, through transcription and posttranscription regulation, HIF- $1 \alpha$ improves the tissues tolerance of hypoxia and ischemia and therefore maintains the oxygen homeostasis.

Researches related HIF-1 has been started, Kido et al. [4] have shown that the over-expression of HIF-1 $\alpha$ can 


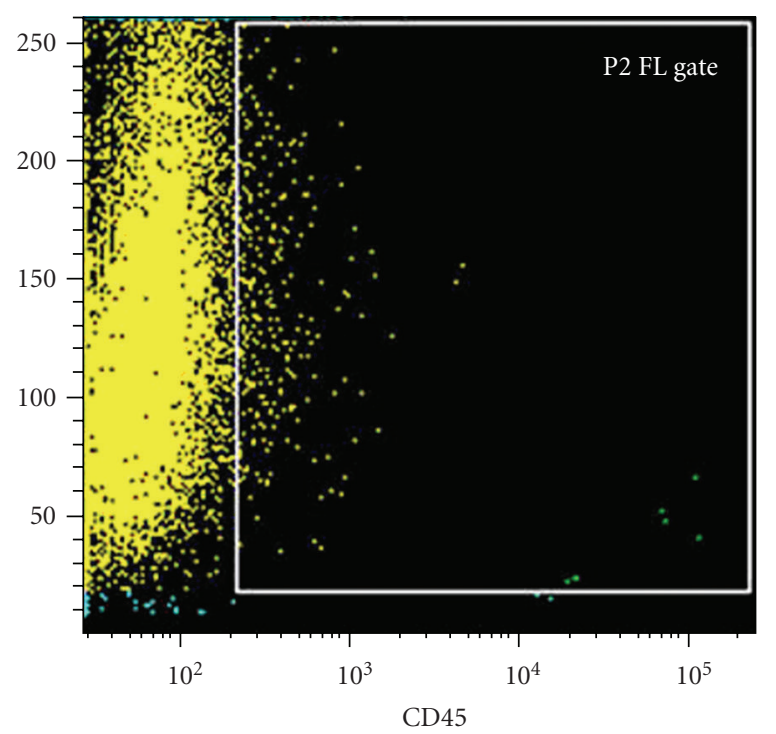

(a)

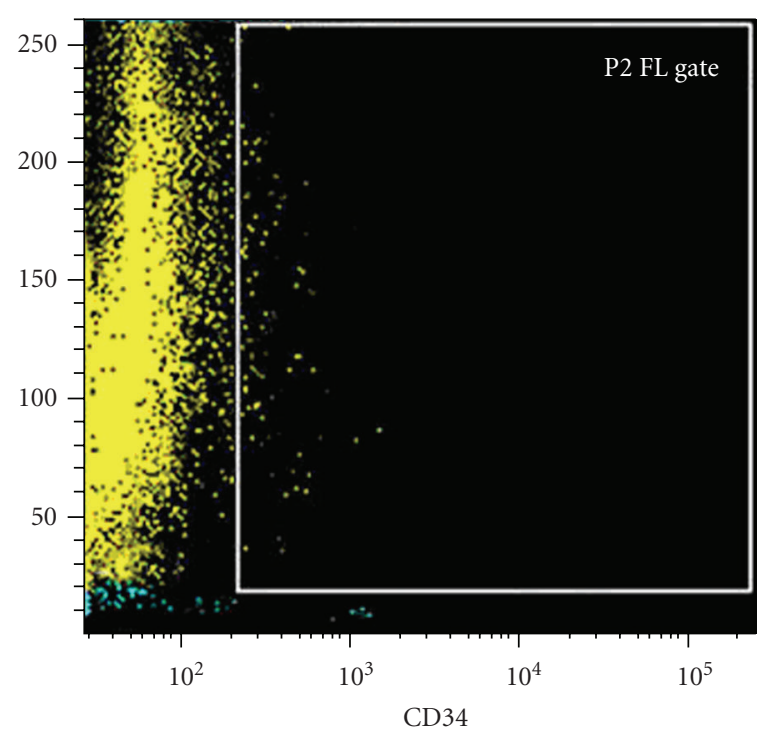

(c)

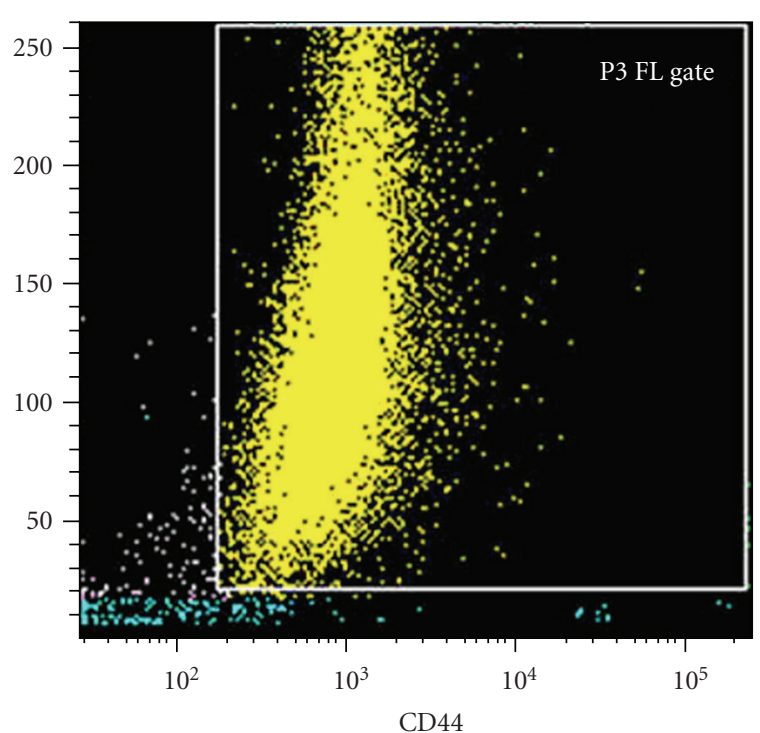

(b)

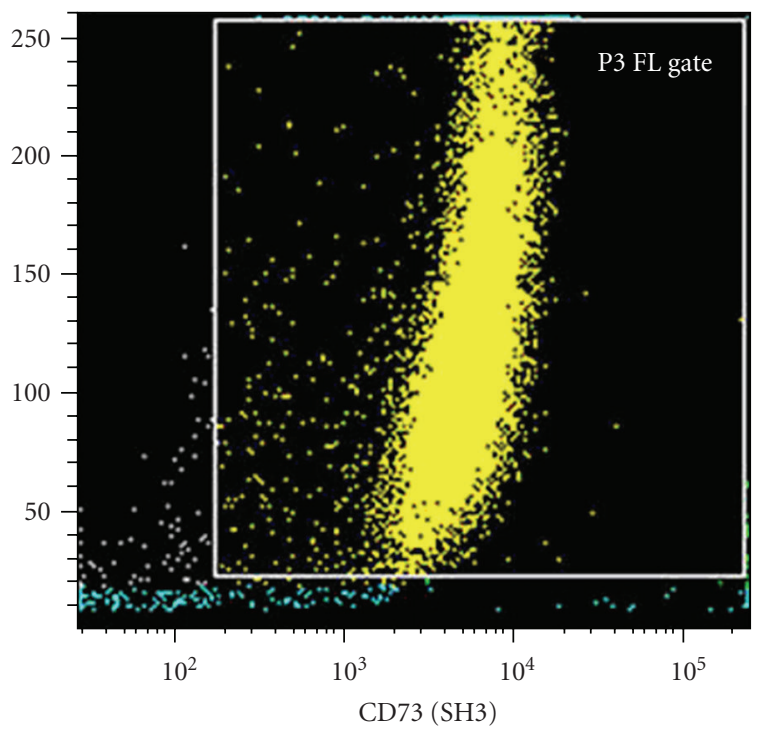

(d)

Figure 5: Cell marker expression CD44 (97.7\%), SH3 (97.3\%), CD34 (3.84\%), and CD45 (2.73\%).

significantly contract the heart-infarcted area 4 weeks after the onset of ischemia, increase the capillary density near the infarcted zone and improve the expression of VEGF and iNOS in transgenic mice which contained HIF- $1 \alpha$ regulated by promoter of myosin $\alpha 2 \mathrm{H}$-chain, indicating the regulation of activity of HIF- $1 \alpha$ may be an effective approach to treat the ischemic heart disease. Lee and his coworkers [5] reported that the myocardium specimen from acute ischemic heart disease patients expressed HIF- $1 \alpha$ gene and the expression of HIF- $1 \alpha$ proceeded to that of VEGF, while the normal myocardium specimen did not express HIF- $1 \alpha$ or VEGF. Lee and his team speculated that the over expression of HIF- $1 \alpha$ is the earliest adaptive reaction at molecular level in case of myocardial ischemia.
Using exogenous angiogenesis factors to facilitate the revascularization of ischemic myocardium is a novel strategy for the advanced severe diffuse coronary heart disease. Recently, exogenous genes VEGF and FGF have drawn the majority attention, though they are just part of lots of genes promoted in the process of angiogenesis. And the effects of VEGF therapy is still under controversy, serial studies have shown the positive effect while some researchers focused on the concern of side effect of VEGF therapy [68 ] including the leakage of newly formed vessels, endothelial dysfunction and infiltration of inflammatory cells. Arbeit et al. [9] amplified HIF-1 by genetic engineering modified mice skin cells, found the gene modified mice had yielded $66 \%$ more capillaries as compared to the control mice and, as 


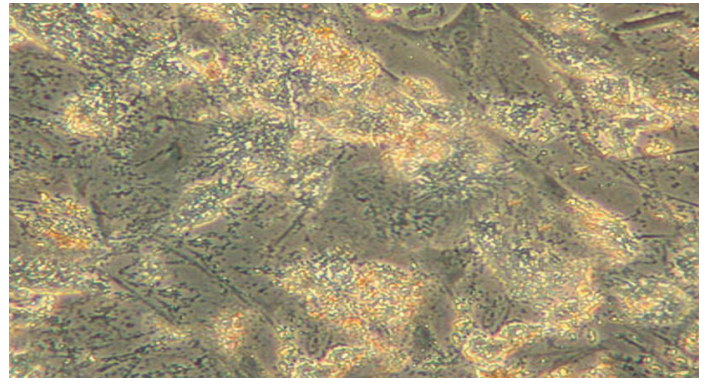

Figure 6: Calcium salinity accumulated after induced culturing $(100 \times)$.

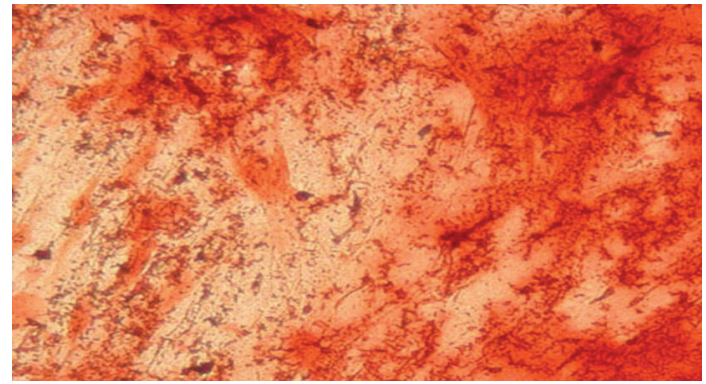

Figure 7: Calcium salts were red when stained by Alizarin S $(100 \times)$.

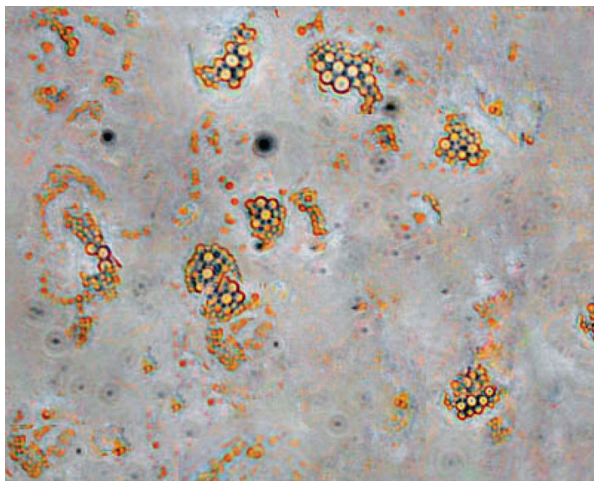

FIGURE 8: Fat drops present after day 14.

expected, higher expression of VEGF, and more importantly, those extra new vessels had normal function without any VEGF associated leakage. Arbeit suggested that regulating the HIF-1 is regulating all the angiogenesis related genes.

Eukaryotic expression vector pcDNA $_{3.1}$ (National Genetic Laboratory, China), designed for the high performance of cDNA in mammalian cell [10], was used in our study to construct the stably effective gene expression vector system. The lengthen of $\mathrm{pcDNA}_{3.1}$ is 5427 bp. pcDNA p $_{3.1}$ has the character of copy easy and stable, and moreover, can be integrated with enhanced green fluorescent protein (eGFP) report gene, which can autocatalysis to form luminous structure and emitting green fluorescent under blue laser. eGFP can be expressed in many kinds of species such as bacterium, myxomycete, yeast, plants and mammal animals without any genus dependence. The fluorescent intensity of eGFP is high enough to be observed

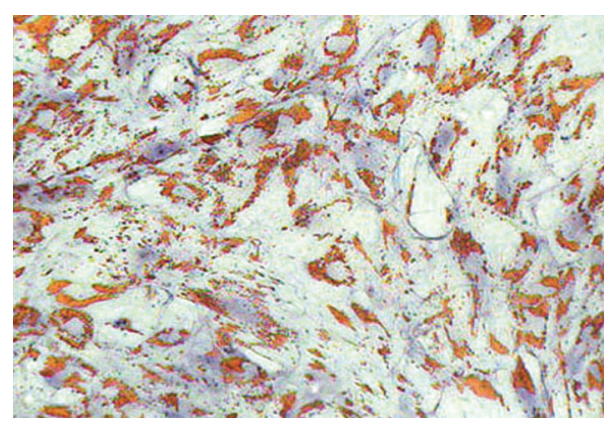

FIGURE 9: Fat drops were red when stained with Sudan IV and nuclei were blue when stained.

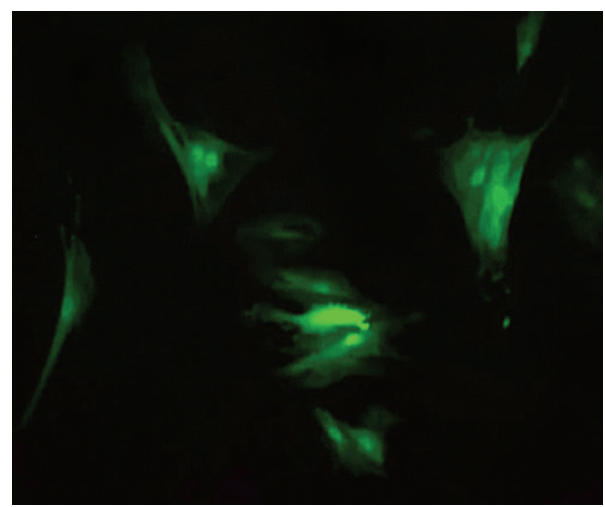

FIgURE 10: MSCs in multiplicative division emit fluorescence.

under common fluorescent microscope and require no reaction substrate or help factors.

The methods of vector construction include cohesive end ligation, blunt end ligation and T-A ligation. Blunt end ligation is direct and simple. Although the ligation efficiency of this method is low, it can be elevated by using some strategies, such as raising the density and ratio of inserted fragment, $5^{\prime}$ phosphorylating the blunt end linear vector, blunting and phosphorylating the PCR products, and adding some ligation accelerators in the system. Some thermostable polymerases, such as Tag DNA polymerase, can perform cohesive end ligation of the PCR products with the $\mathrm{T}$ terminal of vector during the process of amplification and extension. This enzyme improves the efficiency of PCR ligation without further treatment. In this research, we found that PCR products were lost greatly during purification preand postenzyme digestion. So we failed at the beginning, until we increased PCR products leading to the success of ligation. Because the length of the fragment of HIF- $\alpha$ cDNA is greater than $2 \mathrm{~Kb}$, we used high fidelity HotStar enzyme of QIAGEN company in this research, which significantly increased the positive fragment and decreased the nonspecific bands in amplification. The result of amplification was confident and satisfactory for the fragment without any base variation confirmed by sequencing. In this research, HIF$\alpha$ gene was cloned from rat myocardial cells by RT-PCR. Then using $\mathrm{T}$ vector clone method to select positive cone. The cultured bacteria further received plasmia extraction, electrophoresis, and double enzyme digestion. So we can 


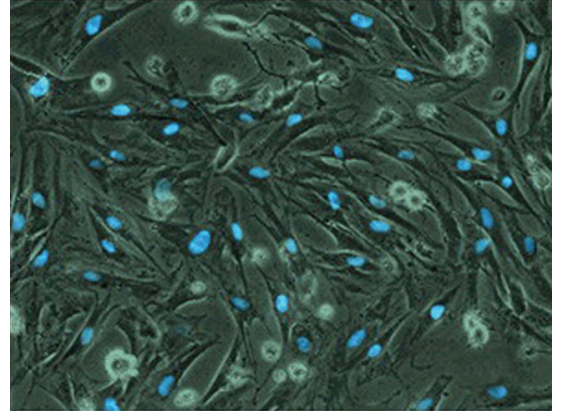

(a)

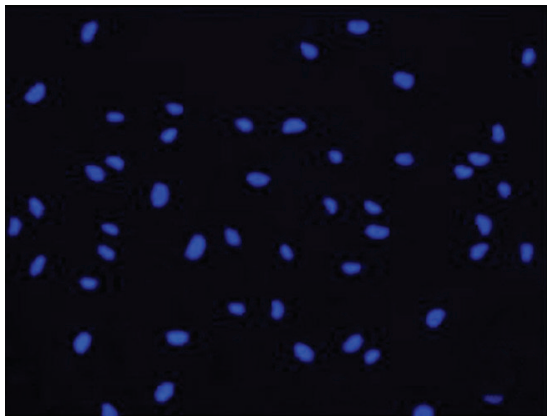

(b)

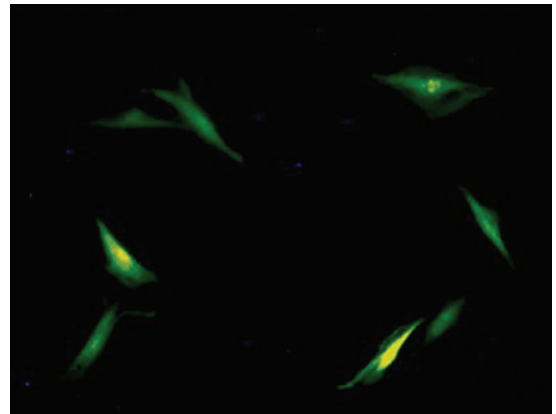

(c)

FIgURE 11: Transfecton efficency $=$ (The number of cells expressing green florescence/The number of cells expressing blue florescence $\times$ $100 \%$, and the average value obtained from $3 \sim 4$ visual field. (a) The cells type and Hoechst33342 stained nucleus that showed light blue under optical microscope. (b) Hoechst33342 can directly permeate the normal membrane and dye the DNA of viable cells, which showed the nucleus expressed blue fluorescence. (c) The cells transfected with HIF- $1 \alpha$-pcDNA ${ }_{3.1} / \mathrm{eGFP}$, showed green fluorescence with whole cell type.
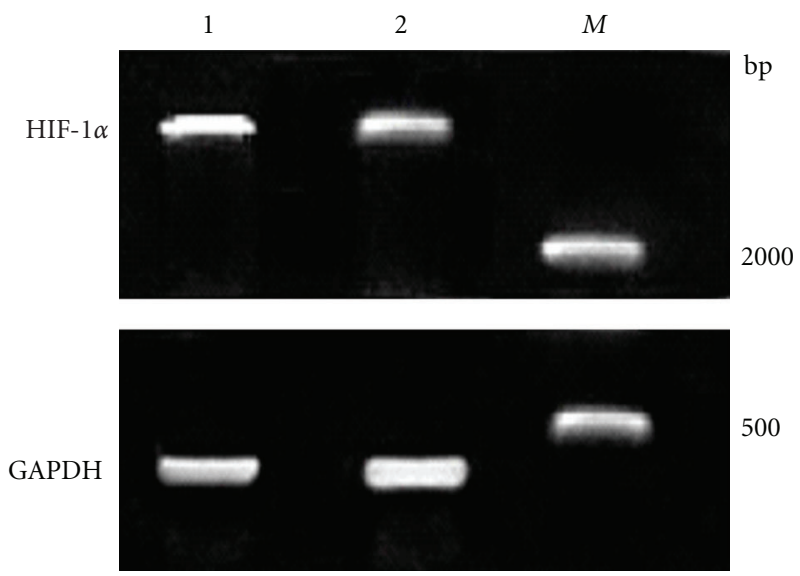

FIgURE 12: Expression of by RT-PCR. Lane 1 was for HIF- $1 \alpha$ $\mathrm{pcDNA}_{3.1}$ transfected MSCs and lane 2 for nontransfected, lane M for DL2000 as reference.

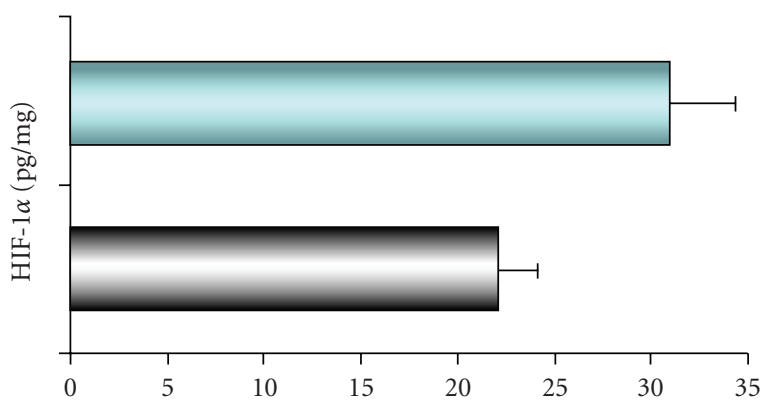

FIgURE 13: Detection of HIF- $1 \alpha$ protein by ELISA. The transfected group (top) had a higher concentration as compared with the nontransfected group.

initially affirm weather exogenous gene (the fragment is about $2.5 \mathrm{~Kb}$ ) is inserted. After confirmed by sequencing, the target fragment was cloned into eukaryotic expression vector $\mathrm{pcDNA}_{3.1}$. It was verified in our research work that this program was convenient, efficient, quick, and reliable, which did some basic work for the further research.

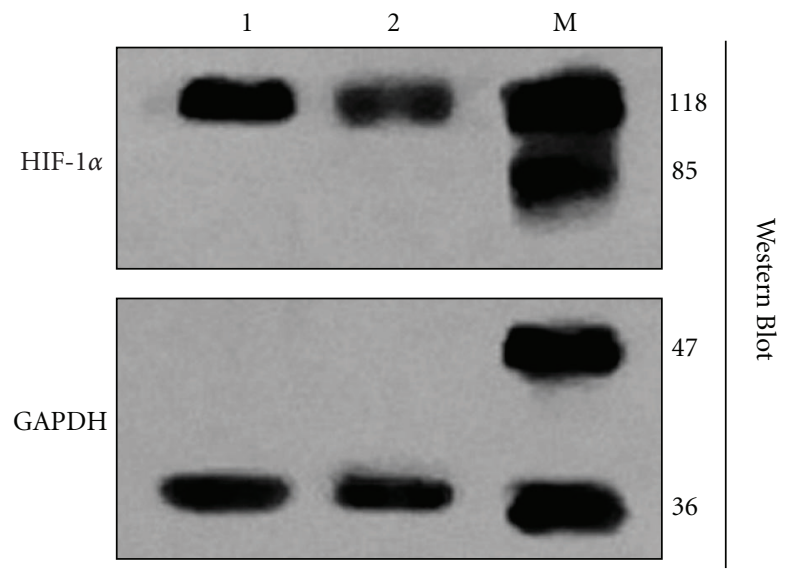

FIGURE 14: Expression of by Western blot. Lane 1 was for HIF- $1 \alpha$ $\mathrm{pcDNA}_{3.1}$ transfected MSCs and lane 2 for nontransfected, lane M (biotinylated protein ladder).

MSCs, early cells of the mesoderm, are cell populations excluding hematopoietic stem cell, have the plasticity to differentiate into multiple tissues. The steady culture system for MSCs has been set up previously [11], and in this culture system, $3 \times 10^{4}$ primary cells can be obtained from each Wistar mouse, and the cell number can be reached to 1 $\times 10^{8}$ after three passages at the rate of $1: 3$. In this study, inspecting the surface antigens with flow cytometry combined with differentiation tests were used to identify cultured MSCs, and we examined four markers, and the cells shown in the result were SH3+, CD34-, CD45-, and CD44+, which are consistent with the quality of MSCs.

How to effectively transfer the target gene, HIF- $1 \alpha$ $\mathrm{pcDNA}_{3.1} / \mathrm{eGFP}$, into the vector cell, MSCs, was the key point of this study. Selections of gene transport vehicle, viral vector or liposome, are associated to the safety of gene therapy directly. Two severe incidents occurred in 1999 and 2002 has raised great concern about the application perspective of viral vector $[12,13]$. Liposomes, composed by phospholipid bilayer, are kind of lipoid containing a hydrophilia inner core. When used as gene transfer vector, liposomes have low 
transfect efficiency but a high safety. The main advantages of liposomes as gene transfer vector are the following: protect the DNA plasmid from degradation by nucleinase, can be biodegradated, easy to manipulate, without immunogenicity, adapted to both separating cells and unseparated cells, and no limitation for the size of exogenous gene. Therefore, positive ion Lipofectmin2000 was chosen as the transfer vector in this study. The transfer efficiency of liposomes is affected by the following parameters [14, 15]: (1) the mix proportion of liposome and DNA; (2) incubation time and (3) the concentration of blood serum in medium. In our study, the expression of exogenous gene was far lower when the MSCs reaching fully confluence and the contact inhibition occurred, as compared to the growth confluence rate of $70-80 \%$, which indicate the cells in mitotic cycle facilitate the expression of exogenous gene transfected by liposomes. The process of entering nuclear is the rate determining step of the transfection mediated by positive ion liposomes, which may be carried by two different ways [16]: (1) passively enter the nuclear during mitotic phase and (2) actively enter the nuclear through the nuclear pore. And therefore, the expression efficiency of exogenous gene is restricted by the mitotic phase which resulting the lower rate of liposomes [17]. For obtaining the best transfection efficiency, we used the best cell density $\left(1 \times 10^{5} / 1 \mathrm{~mL} / \mathrm{hole}\right)$, convergence degree (70 80\% confluence), and transfection reaction time ( 5 hours) recommended by Lipofectmine2000 kit. Referred documents and tested from our preliminary experiment, the best ratio of DNA to liposome volume was DNA: LP2000 $(\mu \mathrm{g}: \mu \mathrm{L})=1$ : 3. It means $3 \mu \mathrm{L} \mathrm{LP} 2000$ mediated $1 \mu \mathrm{g}$ HIF- $1 \alpha$ gene leading to the best transfection efficiency $[18,19]$. In addition, the incubation time is also important. We tried 12 hours, 8 hours, 6 hours, 4 hours, and 2 hours as incubation time, respectively, the result showed that longer incubation time was associated with higher transfection efficiency and higher cellular death rate, while the shorter incubation time could improve the cell survival rate, but the tranfection of exogenous gene was compromised (data not showed in this paper). Finally the 5-hour incubation time was used because both the cell death rate and the transfection efficiency were acceptable. Furthermore, the serum-free DMEM cultivation should be used in the process of transfection. Because the serum contains protein with negative charge and lipid with positive charge, which can reduce the ability of liposome contacting with DNA to form compound.

With hypoxia induction, 48 hours after HIF- $1 \alpha$ pcDNA $_{3.1} /$ eGFP transfecting MSCs mediated by LP2000, the result of RT-PCR showed transgenic MSCs contained mRNA of HIF- $1 \alpha$ protein, which can be verified by HIF$1 \alpha$ expressing in transcriptional level. Immunocytochemistry and ELISA examination showed: transfected cells expressed target product-HIF- $1 \alpha$ protein. Compared with control group, the supernatant of experiment group contained higher HIF- $1 \alpha$ protein. Therefore, we inferred that if transplanting the target cells which received hypoxia induction and transfected within 3 days into ischemic myocardium, the cells can express and secrete HIF- $1 \alpha$ in ischemic circumstance, and in turn, the expressed HIF- $1 \alpha$ can further ameliorate the survival condition of transplanted cells. Through the quantitative experiment, Müller-Ehmsen et al. [20] confirmed that the number of transplanted exogenous cells in myocardium decreased quickly in short time, which maybe related to the apoptosis induced by ischemia and hypoxia. Y. L. Tang et al. [21] found that the tolerance and instability of transplanted cells ameliorated greatly when transplanted MSCs transfected with hypoxia regulated heme oxygenase-1 (HO-1) gene into ischemic myocardium. HO1 gene is the downstream gene of HIF- $1 \alpha$, so transfecting HIF- $1 \alpha$ into MSCs will has more advantage. Now, there is no report of MSCs transfected with HIF- $\alpha$ mediated by liposome transplanting into myocardium at home and abroad. We will make further research in our next experiment in vivo.

Using MSCs as mediated cells in transgenic process can greatly improve the efficiency of HIF- $1 \alpha$ gene treatment. Its advantages include (1) the target cells transplanting after gene transfection in vitro avoids the liposome directly contacting with body, decreasing the potential toxicity; (2) the transfection efficiency and result controllability are satisfactory. It is induced by hypoxia and will not overexpress; (3) cell treatment and gene therapy have synergistic effects. MSCs can differentiate into endothelial cell and cardiac myocyte in microenvironment in vivo and repair damaged myocardium.

Using lipofectamine mediating HIF- $1 \alpha$-pcDNA ${ }_{3.1} / \mathrm{eGFP}$ transfected target cells in vitro, the target gene gets good expression and secretion. To ischemic hart disease with the structure cells lose, this method has the function of killing two birds with one stone. Now, people are making researches in some new liposomes, such as long-circulating liposome, thermosensitive liposome, and ph-sensitive liposome [22]. It can be believed that the transfection efficiency of liposome will be improved in the future. In the process of ischemic heart disease treatment, the strategy of using donorcells with target gene to rebuild the structure of ventricle wall will have favorable prospect of development in the forthcoming biotherapy.

\section{Acknowledgments}

The authors appreciate the Committee of Provincial Science Study Foundation of HuNan (China) for their providing funds (no. 05FJ3027). They also express their gratitude to "Aid Program for Science and Technology Innovative Research Team in Higher Educational Institutions of Hunan Province."

\section{References}

[1] Z. Haizheng and G. Jihong, "Epidemiology and primary prevention of coronary artery disease," Chinese Journal of Practical Internal Medicine, vol. 22, no. 8, pp. 449-451, 2002.

[2] J. Kastrup, E. Jørgensen, A. Rück, et al., "Direct intramyocardial plasmid vascular endothelial growth factor- $\mathrm{A}_{165}$ gene therapy in patients with stable severe angina pectoris: a randomized double-blind placebo-controlled study: the Euroinject One trial," Journal of the American College of Cardiology, vol. 45, no. 7, pp. 982-988, 2005. 
[3] R. S. Ripa, Y. Wang, E. Jørgensen, H. E. Johnsen, B. Hesse, and J. Kastrup, "Intramyocardial injection of vascular endothelial growth factor- $\mathrm{A}_{165}$ plasmid followed by granulocyte-colony stimulating factor to induce angiogenesis in patients with severe chronic ischaemic heart disease," European Heart Journal, vol. 27, no. 15, pp. 1785-1792, 2006.

[4] M. Kido, L. Du, C. C. Sullivan, et al., "Hypoxia-inducible factor 1- $\alpha$ reduces infarction and attenuates progression of cardiac dysfunction after myocardial infarction in the mouse," Journal of the American College of Cardiology, vol. 46, no. 11, pp. 2116-2124, 2005.

[5] S. H. Lee, P. L. Wolf, R. Escudero, R. Deutsch, S. W. Jamieson, and P. A. Thistlethwaite, "Early expression of angiogenesis factors in acute myocardial ischemia and infarction," The New England Journal of Medicine, vol. 342, no. 9, pp. 626-633, 2000.

[6] D. Orlic, J. Kajstura, S. Chimenti, et al., "Bone marrow cells regenerate infarcted myocardium," Nature, vol. 410, no. 6829, pp. 701-705, 2001.

[7] H. Takano, M. Ohtsuka, H. Akazawa, et al., "Pleiotropic effects of cytokines on acute myocardial infarction: G-CSF as a novel therapy for acute myocardial infarction," Current Pharmaceutical Design, vol. 9, no. 14, pp. 1121-1127, 2003.

[8] D. Orlic, J. Kajstura, S. Chimenti, et al., "Mobilized bone marrow cells repair the infarcted heart, improving function and survival," Proceedings of the National Academy of Sciences of the United States of America, vol. 98, no. 18, pp. 1034410349, 2001.

[9] J. M. Arbeit, "Quiescent hypervascularity mediated by gain of HIF- $1 \alpha$ function," Cold Spring Harbor Symposia on Quantitative Biology, vol. 67, pp. 133-142, 2002.

[10] J. Sambrook, E. F. Fritsch, and T. Maniatis, Molecular Cloning: A Laboratory Manual, Cold Spring Harbor Laboratory, New York, NY, USA, 1989.

[11] Z. Wen-Wu, H. Jian-Guo, M. Yan-Ling, et al., "Experimental study of the transfection of human VEGF165 gene into rat bone mes enchymal stem cells in vitro," Life Science Research, vol. 9, no. 4, pp. 301-307, 2005.

[12] S. Lehrman, "Virus treatment questioned after gene therapy death," Nature, vol. 401, no. 6753, pp. 517-518, 1999.

[13] E. Marshall, "Clinical research: gene therapy a suspect in leukemia-like disease," Science, vol. 298, no. 5591, pp. 34-35, 2002.

[14] S. J. Eastman, J. D. Tousignant, M. J. Lukason, et al., "Optimization of formulations and conditions for the aerosol delivery of functional cationic lipid: DNA complexes," Human Gene Therapy, vol. 8, no. 3, pp. 313-322, 1997.

[15] P. L. Felgner, "Improvements in cationic liposomes for in vivo gene transfer," Human Gene Therapy, vol. 7, no. 15, pp. 17911793, 1996.

[16] M. A. Zanta, P. Belguise-Valladier, and J.-P. Behr, "Gene delivery: a single nuclear localization signal peptide is sufficient to carry DNA to the cell nucleus," Proceedings of the National Academy of Sciences of the United States of America, vol. 96, no. 1, pp. 91-96, 1999.

[17] P. Zhang, H. Zhang, S. S. Hu, L. G. Chen, and Y. J. Wei, "Plasmid transfection of rat bone marrow mesenchymal stem cells by cationic lipid for gene-modified cell transplantation therapy," Acta Academiae Medicinae Sinicae, vol. 27, no. 4, pp. 504-508, 2005.

[18] J. A. Forsythe, B. H. Jiang, N. V. Iyer, et al., "Activation of vascular endothelial growth factor gene transcription by hypoxia-inducible factor 1," Molecular and Cellular Biology, vol. 16, no. 9, pp. 4606-4613, 1996.
[19] J. Waltenberger, U. Mayr, S. Pentz, and V. Hombach, "Functional upregulation of the vascular endothelial growth factor receptor KDR by hypoxia," Circulation, vol. 94, no. 7, pp. 1647-1654, 1996.

[20] J. Müller-Ehmsen, P. Whittaker, R. A. Kloner, et al., "Survival and development of neonatal rat cardiomyocytes transplanted into adult myocardium," Journal of Molecular and Cellular Cardiology, vol. 34, no. 2, pp. 107-116, 2002.

[21] Y. L. Tang, Y. Tang, Y. C. Zhang, K. Qian, L. Shen, and M. I. Phillips, "Improved graft mesenchymal stem cell survival in ischemic heart with a hypoxia-regulated heme oxygenase1 vector," Journal of the American College of Cardiology, vol. 46, no. 7, pp. 1339-1350, 2005.

[22] V. A. S. Carmo, M. C. De Oliveira, E. C. O. Reis, et al., "Physicochemical characterization and study of in vitro interactions of $\mathrm{pH}$-sensitive liposomes with the complement system," Journal of Liposome Research, vol. 18, no. 1, pp. 5970, 2008. 

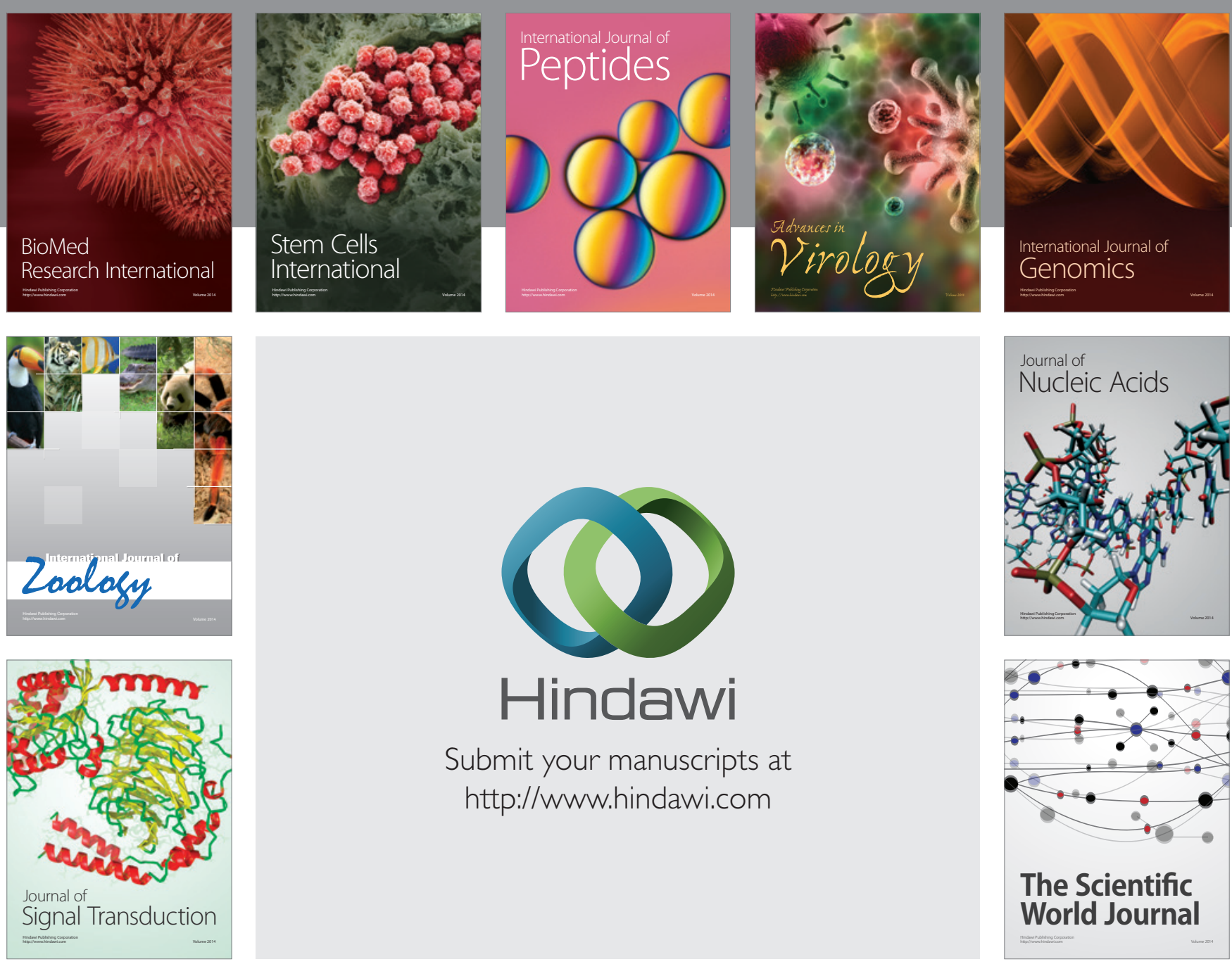

Submit your manuscripts at

http://www.hindawi.com
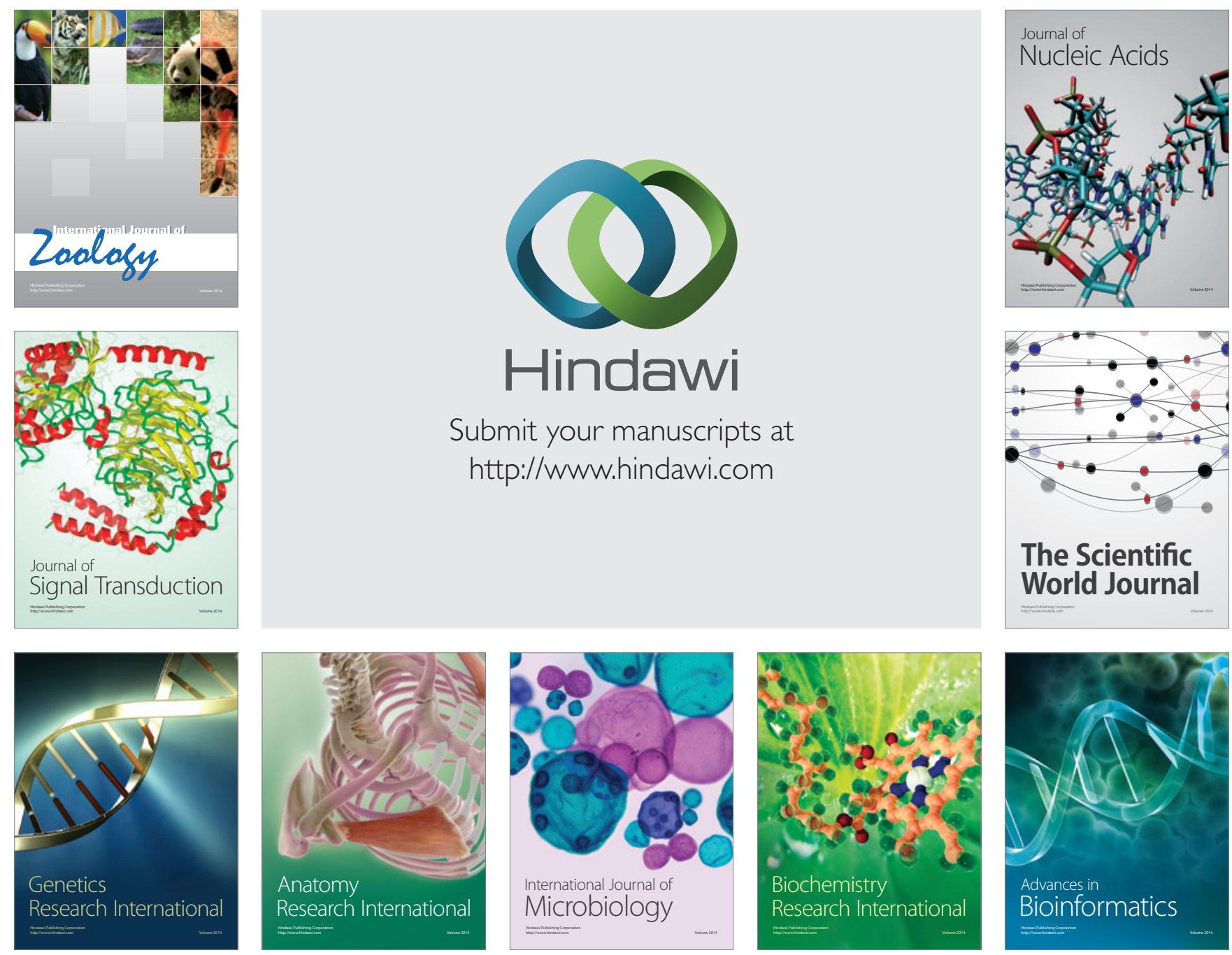

The Scientific World Journal
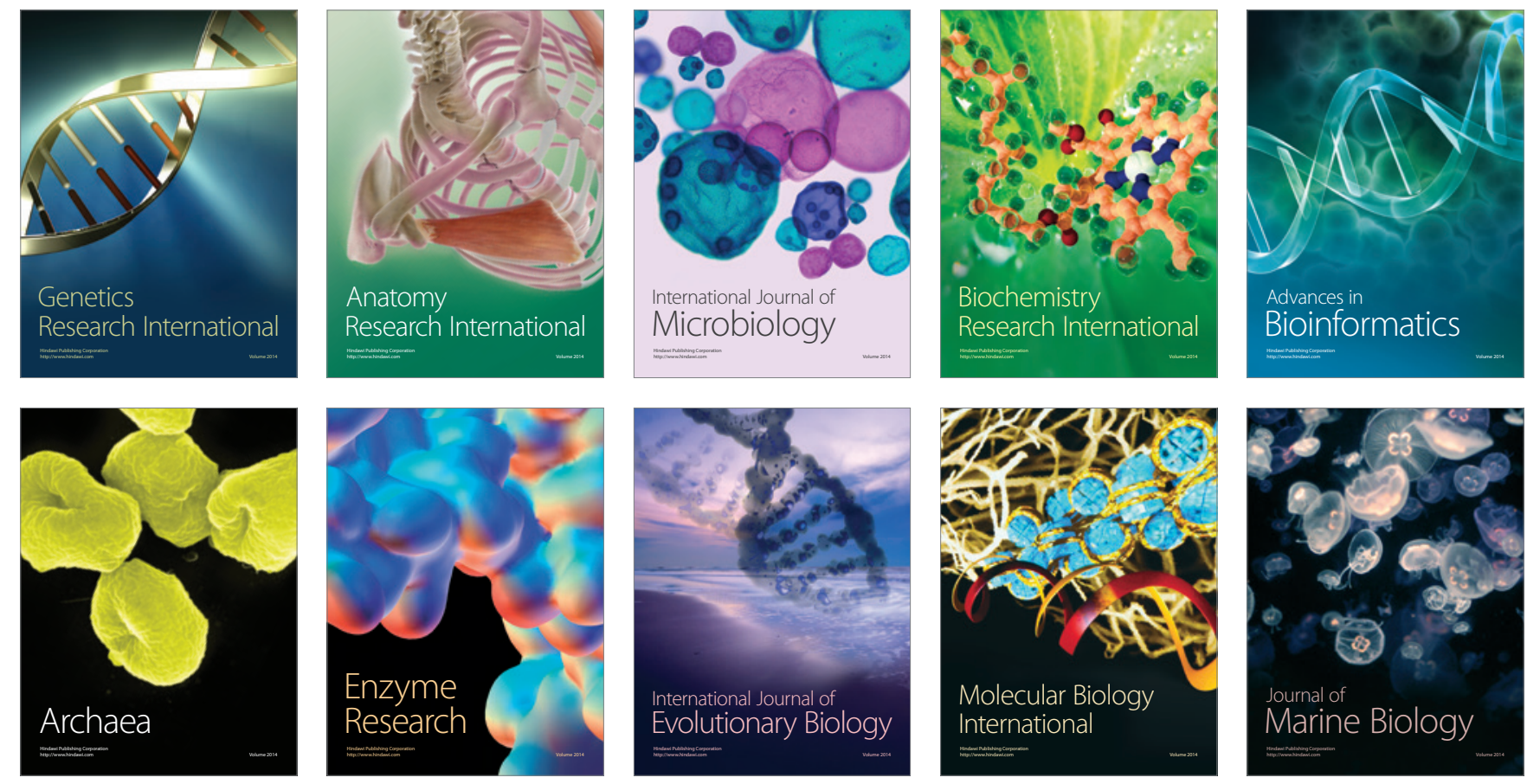